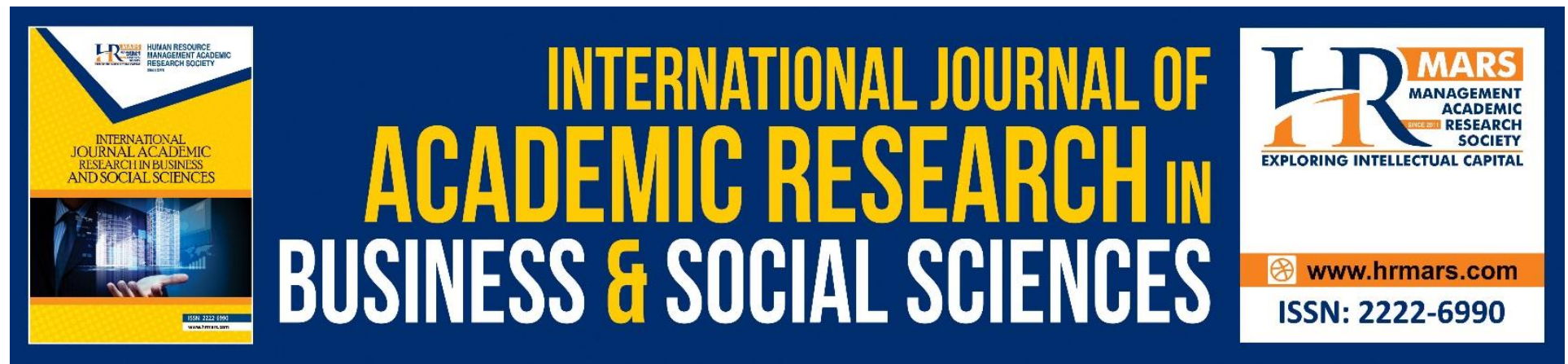

\title{
Validity and Reliability of the Malaysian Perceived Stress Scale (PSS) using Rasch Measurement Model
}

\section{Zainab Tambol, Abu Yazid Abu Bakar \& Mohd Izwan Mahmud}

To Link this Article: http://dx.doi.org/10.6007/IJARBSS/v11-i8/10770

DOI:10.6007/IJARBSS/v11-i8/10770

Received: 09 June 2021, Revised: 11 July 2021, Accepted: 30 July 2021

Published Online: 12 August 2021

In-Text Citation: (Tambol et al., 2021)

To Cite this Article: Tambol, Z., Bakar, A. Y. A., \& Mahmud, M. I. (2021). Validity and Reliability of the Malaysian Perceived Stress Scale (PSS) using Rasch Measurement Model. International Journal of Academic Research in Business and Social Sciences, 11(8), 667-677.

Copyright: (C) 2021 The Author(s)

Published by Human Resource Management Academic Research Society (www.hrmars.com)

This article is published under the Creative Commons Attribution (CC BY 4.0) license. Anyone may reproduce, distribute, translate and create derivative works of this article (for both commercial and non-commercial purposes), subject to full attribution to the original publication and authors. The full terms of this license may be seen at: http://creativecommons.org/licences/by/4.0/legalcode

Vol. 11, No. 8, 2021, Pg. 667 - 677

http://hrmars.com/index.php/pages/detail/IJARBSS

JOURNAL HOMEPAGE

Full Terms \& Conditions of access and use can be found at http://hrmars.com/index.php/pages/detail/publication-ethics 


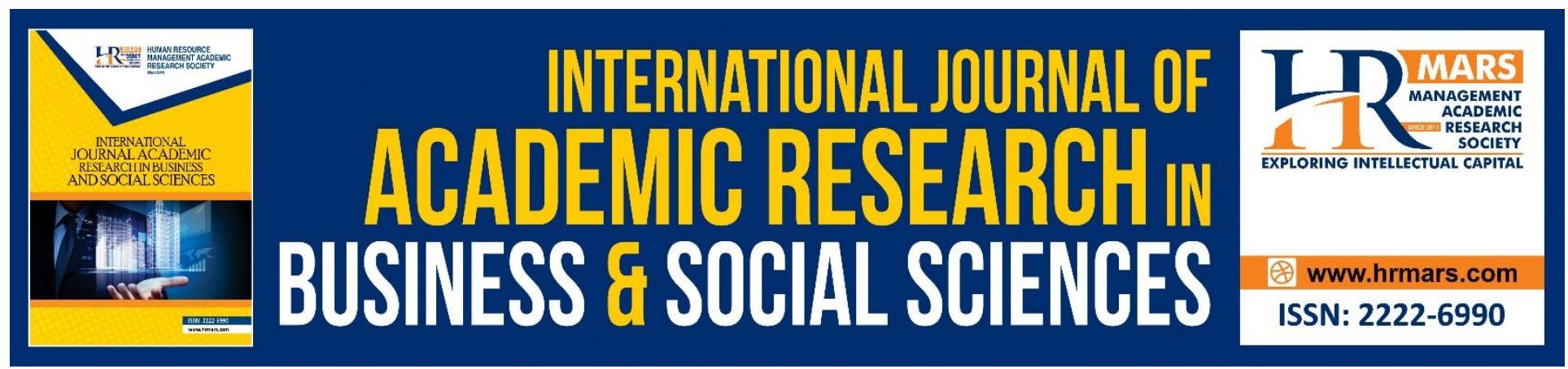

\title{
Validity and Reliability of the Malaysian Perceived Stress Scale (PSS) using Rasch Measurement Model
}

\author{
Zainab Tambol, Abu Yazid Abu Bakar \& Mohd Izwan Mahmud \\ Faculty of Education, Universiti Kebangsaan Malaysia, Selangor, MALAYSIA \\ Email: yazid3338@ukm.edu.my
}

\begin{abstract}
This study was conducted to produce empirical evidence of validity and reliability of the item using a survey questionnaire Perceived Stress Scale. The 14-item Perceived Stress Scale (PSS-14) is one of the most widely used psychological instruments for measuring stress perception in practice and research works, but has sparked some controversy regarding its factor structure. Furthermore, no study has been conducted to date using a sample of 'houseman' medical officers to test the reliability and validity of this instrument. The Rasch model analysis, aided by Winsteps software Version 3.69.1.11, was used to examine the functional items from the reliability and separation of item and respondent, polarity and items fit measuring constructs and standardized residual correlation value. The questionnaire was distributed to 42 'houseman' officers who work in a hospital in Selangor, Malaysia. The findings of this study support the use of the PSS-14 as a reliable and valid instrument to assess perceived stress in a sample of 'houseman' medical officers in Malaysia.
\end{abstract}

Keywords: Perceived Stress Scale (PSS), Rasch Model, Validity and Reliability, Malaysia

\section{Introduction}

Rasch measurement model has proven that learning transfer questionnaire has a level of validity and reliability then be used to develop a model of learning transfer. This is because the use of Rasch measurement model is a solution to the issue of validity as Rasch measurement model provides useful statistics and offers a tremendous opportunity to probe the validity (Bond \& Fox, 2015). In addition, the application of Rasch measurement model in a study will be able to facilitate and produce a more efficient, reliable and valid measurement while increasing convenience to user (Abdul Aziz et al., 2007).

A study to identify the validity and reliability of the instrument is very important for maintaining the accuracy of the questionnaire (Ariffin et al., 2010). This is necessary to determine the questionnaire to measure what is to be measured consistently and accurately. According to Howard and Braun (1988), consistency means that when the same item is tested several time on 
the same subject at a different time interval, the score result given is approximately the same. In conclusion, the reliability is likely to provide a consistent validity. This study was performed to produce empirical evidence of the validity and reliability of Perceived Stress Scale questionnaire using Rasch measurement model. This is because the Rasch measurement model can test the consistency of interpretation of constructs, the reliability of the items and the respondent and the accuracy of the test.

The Perceived Stress Scale has been used by many researchers around the world such as general public, school students, patients, seniors, athletes and teenagers (refer Table 1). Out of the 19 research works listed in Table 1, 15 used SPSS to analyze the data obtained, while four studies used Rasch Model to analyze the data. This indicates that SPSS is a statistical mechanism that is still widely used in research compared to the Rasch Model in order to determine the instrument's validity and reliability values. This table also shows that the Perceived Stress Scale was administered to adults, adolescents, seniors, medical students, nurses, teachers, health 'frontliners', university students, and pregnant women.

Hence, in this study, the researchers use 'houseman' medical doctors as the study respondents. In fact, researchers also use the Rasch Model as a statistical mechanism to determine the validity and reliability of the PSS-14 items. Therefore, the objectives of this analysis are to:

a. test the reliability and item separation index and the respondent

b. detect the polarity items that measure the constructs

c. test the item fit of the instrument items

In other words, this paper aims to discuss the findings of Perceived Stress Scale (PSS-14) validation study in Malaysian context. It is not only meant for establishing the validity and reliability of the instrument in Malaysian population of 'houseman' medical doctors, but most importantly, to add and increase such research works which use Rasch Measurement Model as a statistical analysis mechanism. 
Table 1: The use of Perceived Stress Scale (PSS) in research works within 2015-2020

\begin{tabular}{|c|c|c|c|c|}
\hline Article \& Author & Respondents & Year & Version & $\begin{array}{l}\text { Statistical } \\
\text { Analysis }\end{array}$ \\
\hline Measuring Stress - Methods and Tools & Romanian Adults & 2020 & Romanian & SPSS \\
\hline $\begin{array}{l}\text { Measuring Stress in Australia: Validation of the Perceived Stress Scale (PSS- } \\
\text { 14) in a National Sample }\end{array}$ & Australian Citizens & 2020 & English & Rasch Model \\
\hline $\begin{array}{l}\text { The Examination of Sleep Quality for Frontline Healthcare Workers during } \\
\text { the Outbreak of COVID-19 }\end{array}$ & $\begin{array}{l}\text { Healthcare } \\
\text { 'Frontliners' }\end{array}$ & 2020 & English & SPSS \\
\hline $\begin{array}{l}\text { Correlation between Stress Scores and Self-Regulated Learning Perception } \\
\text { Scores in Pakistani Students }\end{array}$ & $\begin{array}{l}1^{\text {st }}-5^{\text {th }} \text { Year Medical } \\
\text { Students }\end{array}$ & 2020 & English & SPSS \\
\hline $\begin{array}{l}\text { Stress beyond Coping? A Rasch analysis of the Perceived Stress Scale (PSS- } \\
\text { 14) in an Aboriginal Population }\end{array}$ & Aboriginal Women & 2019 & English & Rasch Model \\
\hline $\begin{array}{l}\text { Construct Validity of the Perceived Stress Scale (PSS-14) in a Sample of Early } \\
\text { Childhood Teacher Candidates }\end{array}$ & $\begin{array}{l}\text { Korean University } \\
\text { Students }\end{array}$ & 2019 & English & SPSS \\
\hline $\begin{array}{l}\text { Cross-cultural Validation of the Student Nurse Stress Index Scale: A } \\
\text { Descriptive Survey targeting Student Nurses in China }\end{array}$ & $\begin{array}{l}\text { China Nursing } \\
\text { Students }\end{array}$ & 2019 & Chinese & SPSS \\
\hline $\begin{array}{l}\text { Psychometric Properties of the Perceived Stress Scale in a Sample of } \\
\text { German Dementia Patients and their Caregivers }\end{array}$ & German Citizens & 2018 & English & SPSS \\
\hline $\begin{array}{l}\text { The Vietnamese Version of the Perceived Stress Scale (PSS-10): Translation } \\
\text { Equivalence and Psychometric Properties among Older Women }\end{array}$ & $\begin{array}{l}\text { Vietnamese Old } \\
\text { Women }\end{array}$ & 2017 & Vietnamese & SPSS \\
\hline $\begin{array}{l}\text { Validity and Reliability of the Cohen } 10 \text {-item Perceived Stress Scale in } \\
\text { Patients with Chronic Headache: Persian Version }\end{array}$ & Persian Citizens & 2017 & Persian & SPSS \\
\hline $\begin{array}{l}\text { Perceived Stress Scale: Confirmatory Factor Analysis of the PSS-14 and PSS- } \\
10 \text { Versions in Two Samples of Pregnant Women from the BRISA cohort }\end{array}$ & Pregnant Women & 2017 & Chinese & SPSS \\
\hline $\begin{array}{l}\text { Psychometric Evaluation of Turkish Version of the Perceived Stress Scale } \\
\text { with Turkish College Students }\end{array}$ & $\begin{array}{l}\text { Turkish College } \\
\text { Students }\end{array}$ & 2017 & Turkish & SPSS \\
\hline $\begin{array}{l}\text { Rasch Analysis of the Perceived Stress Scale: Transformation from an } \\
\text { Ordinal to a Linear Measure }\end{array}$ & Students & 2017 & English & Rasch Model \\
\hline
\end{tabular}


INTERNATIONAL JOURNAL OF ACADEMIC RESEARCH IN BUSINESS AND SOCIAL SCIENCES

Vol. 11, No. 8, 2021, E-ISSN: 2222-6990 @ 2021 HRMARS

\begin{tabular}{|c|c|c|c|c|}
\hline $\begin{array}{l}\text { The German Version of the Perceived Stress Scale (PSS-10): Evaluation of } \\
\text { Dimensionality, Validity, and Measurement Invariance with Exploratory } \\
\text { and Confirmatory Bifactor Modeling }\end{array}$ & $\begin{array}{c}\text { Registrants of } \\
\text { Statutory Health } \\
\text { Insurance Company }\end{array}$ & 2017 & German & SPSS \\
\hline $\begin{array}{l}\text { Psychometric Properties of the Perceived Stress Scale (PSS): Measurement } \\
\text { Invariance between Athletes and Non-Athletes }\end{array}$ & $\begin{array}{l}\text { Athletes and Non- } \\
\text { Athletes }\end{array}$ & 2016 & English & SPSS \\
\hline The Construct Validity of the Perceived Stress Scale & General Public & 2016 & English & Rasch Model \\
\hline $\begin{array}{l}\text { Reliabilty and Validity of the 4-item Version of the Korean Perceived Stress } \\
\text { Scale }\end{array}$ & Nursing Students & 2016 & Korean & SPSS \\
\hline $\begin{array}{l}\text { Korean Versions of the Perceived Stress Scale (PSS-14, } 10 \text { and 4): } \\
\text { Psychometric Evaluation in Patients with Chronic Disease }\end{array}$ & $\begin{array}{l}\text { Chronic Disease } \\
\text { Patients }\end{array}$ & 2016 & English & SPSS \\
\hline $\begin{array}{l}\text { Cross-cultural Adaptation and Validation of the Danish Consensus Version } \\
\text { of the } 10 \text {-item Perceived Stress Scale }\end{array}$ & Outpatients & 2015 & Danish & SPSS \\
\hline
\end{tabular}




\section{Methodology}

The Perceived Stress Scale (PSS) was developed by Cohen et al. (1983) in order to measure the extent to which situations in one's life are appraised as stressful. Several alternate versions of the PSS exist, which vary in the number of items used to describe perceived stress. There are three versions of the PSS, namely PSS-14, PSS-10 and PSS-4 (Cohen \& Williamson, 1988). Thus, Lee (2012) conducted a comprehensive review of the psychometric properties of the PSS and reported that all versions of the PSS have acceptable psychometric properties. This study employs a survey by distributing questionnaires developed by Cohen and his colleagues. The questionnaire consists of 14 items, on 5-point Likert scale. The PSS 14 Questionnaires were distributed to 42 house officers who are working at a government hospital in Selangor, Malaysia.

The number of respondents in the pilot study was adequate because, according to Cooper \& Schindler 2012, the number of respondents who suitable for the pilot study is between 25 to 100 people. Whereas, Johanson and Brooks (2010) suggest a minimum number of 30 people for a pilot study in which the aim is to study early or development scale. Data were analyzed with the aid of the software Winsteps version 3.69.1.11.

\section{Results}

Through Rasch measurement model approach, the researchers perform an examination of the item functional in terms of:
a. item reliability and separation of the respondents
b. detecting polarity items that measure the constructs based on the PTMEA CORR
c. items fit measuring constructs

\section{Reliability and Separation Items and Respondent}

Based on Rasch measurement model approach, the acceptable reliability Cronbach's Alpha $(\alpha)$ is between $0.71-0.99$, where it is at the best level (71\% - 99\%). The findings of the pilot study found that the reliability obtained based on the Cronbach Alpha (KR 20) is 0.88 . This indicates that this instrument is a reliable instrument and suitable for the specified sample. dSo this value shows instruments used are in very good condition and effectively with a high level of consistency thus can be used in the actual research.

The analysis also performed on the instrument as a whole, namely the reliability and the separation of the item and the respondent. Table 2 shows the reliability and separation items where the reliability of the items was 0.95 , while the separation of items is 4.50 . Based on the reliability of the items, the value of 0.95 indicates are in good condition and acceptable (Bond \& Ford, 2007). According to Linacre (2004), the separation index is better when the value is more than the value of 2.0 .

While the reliability of the respondents is 0.88 , and the separation of the respondents is 2.46. This shows that the respondents are very high reliability and very good. This is because Bond and Fox (2007) describe the reliability of more than 0.8 is good and stronger acceptable. While the separation of the respondents showed good separation of the item difficulty level appropriate to the Linacre (2004), which describes the separation of more than 2.0 is a good value. 
Table 2: Reliability and Separation Item and Respondent for the Entire Construct Instruments: Pilot Study

SUMMARY OF 14 MEASURED Item

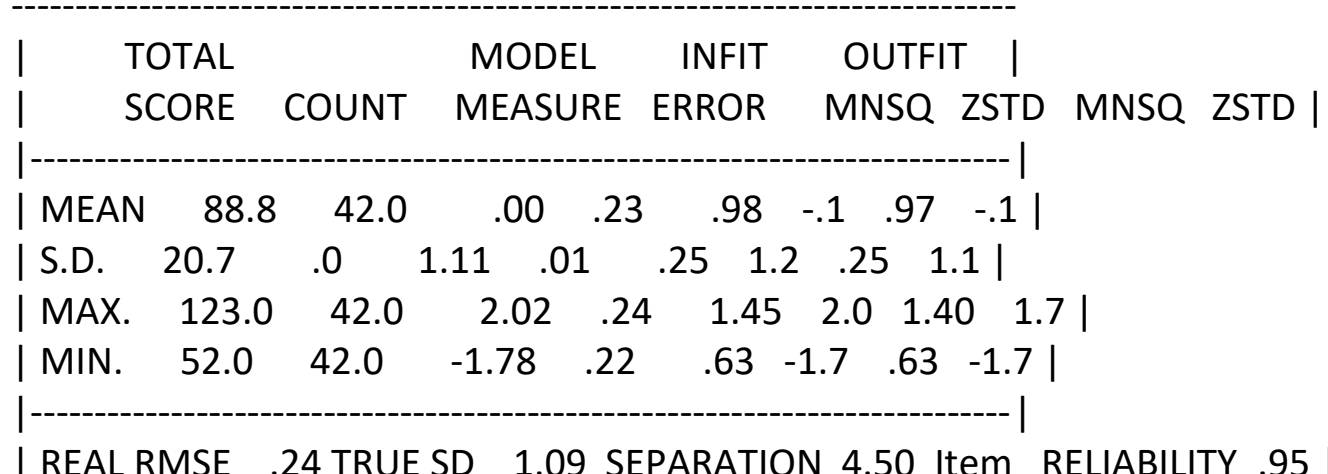

| REAL RMSE .24 TRUE SD 1.09 SEPARATION 4.50 Item RELIABILITY .95 | |MODEL RMSE .23 TRUE SD 1.09 SEPARATION 4.72 Item RELIABILITY .96 | | S.E. OF Item MEAN = .31

SUMMARY OF 42 MEASURED Person

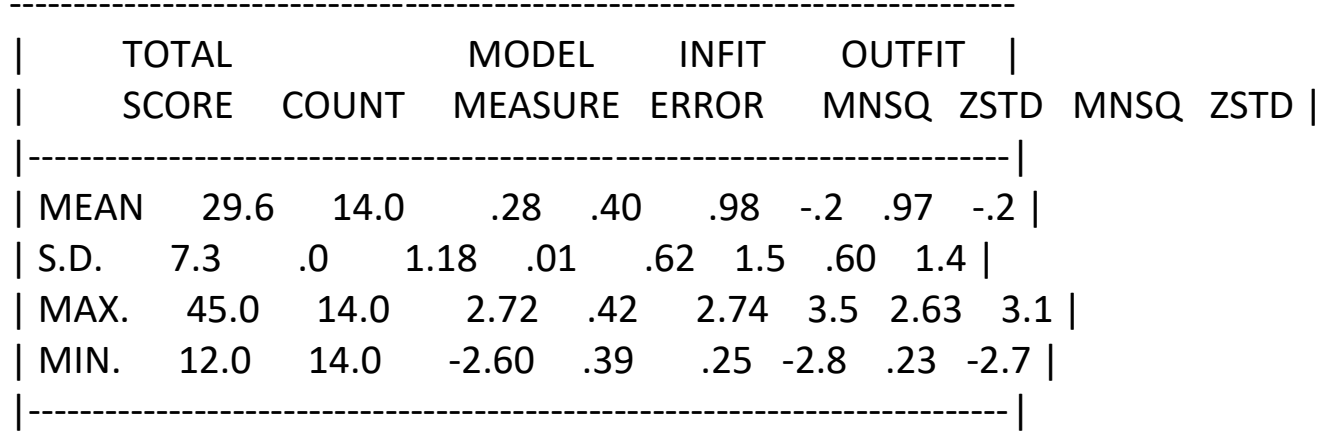

| REAL RMSE $\quad .44$ TRUE SD 1.09 SEPARATION $\underline{2.46}$ Person RELIABILITY $\underline{.86}$ | |MODEL RMSE $\quad$.40 TRUE SD 1.11 SEPARATION 2.77 Person RELIABILITY .88 | I S.E. OF Person MEAN = .18

Person RAW SCORE-TO-MEASURE CORRELATION $=1.00$

CRONBACH ALPHA (KR-20) Person RAW SCORE RELIABILITY $=.88$

\section{Polarity Item by PTMEA CORR Value}

The Point Measure Correlation (PTMEA CORR.) is to detect polarity items intended to test the extent to which the construction of constructs achieves its goal. If the value contained in the PTMEA CORR is the positive $(+)$, it shows the item measure the constructs to be measured (Bond \& Ford, 2007). On the other hand, if the value is negative $(-)$, the item is not developed to measure the constructs to be measured. Thus it needs to be improved or dropped because the item is not lead to the question (not focus) or difficult to answer by the respondent.

Based on Table 3, there are all items that get PTMEA CORR. are positive, which indicates that the items measuring the constructs to be measured (Bond \& Ford 2007). Whereas, the negative PTMEA CORR indicated item needs to give attention or should be repaired or removed. The rest of PTMEA CORR. is positive despite the lowest positive value of item S4 (0.43), S10 (0.46), and S12 (0.41). Thus purification items should be done. However, based on these findings show that positive items moving in one direction with construct and able to 
measure constructs and does not conflict with the constructs being measured. If the PTMEA CORR. is high, then the item is able to distinguish between respondents capability.

Table 3: A Part of Point Measure Correlation Value

\begin{tabular}{|c|c|c|c|c|c|c|c|}
\hline & \multicolumn{2}{|c|}{ OUTFIT } & \multicolumn{2}{|c|}{ PT-Measure } & \multirow{2}{*}{$\begin{array}{c}\text { Exact } \\
\text { OBS\% }\end{array}$} & \multirow{2}{*}{$\begin{array}{c}\text { Match } \\
\text { EXP\% }\end{array}$} & \multirow{2}{*}{ Item } \\
\hline & MNSQ & ZSTD & CORR. & EXP. & & & \\
\hline & 1.38 & 1.7 & .41 & .61 & 50.0 & 50.1 & S12 \\
\hline & 1.40 & 1.7 & .43 & .61 & 54.8 & 53.9 & S4 \\
\hline & 1.22 & 1.0 & .46 & .61 & 54.8 & 56.5 & S10 \\
\hline & 1.30 & 1.2 & .51 & .61 & 42.9 & 58.3 & S13 \\
\hline & .95 & -0.1 & .58 & .63 & 54.8 & 57.3 & S6 \\
\hline & .93 & -0.2 & .60 & .62 & 61.9 & 54.2 & S5 \\
\hline & .95 & -0.1 & .63 & .62 & 61.9 & 59.6 & S9 \\
\hline & .63 & -1.7 & .64 & .62 & 69.0 & 59.7 & S7 \\
\hline & .78 & -1.0 & .65 & .61 & 59.5 & 49.7 & S1 \\
\hline & .83 & -0.8 & .72 & .62 & 54.8 & 51.8 & S3 \\
\hline & .74 & -1.2 & .72 & .61 & 57.1 & 51.4 & S11 \\
\hline & .93 & -0.2 & .74 & .61 & 50.0 & 55.8 & S8 \\
\hline & .72 & -1.4 & .77 & .61 & 54.8 & 49.7 & S2 \\
\hline & .80 & -0.8 & .78 & .61 & 66.7 & 58.3 & S14 \\
\hline MEAN & .97 & -0.1 & & & 56.6 & 54.7 & \\
\hline S.D & .25 & 1.1 & & & 6.6 & 3.6 & \\
\hline
\end{tabular}

Item Fit Measure Constructs

Items fit measures the constructs that can be seen through the infit and outfit Mean Square (MNSQ). According to Bond and Fox (2007), the outfit and infit MNSQ should be in the range of 0.6 to 1.4 to ensure the items are suitable for measuring the constructs. If the infit or outfit MNSQ value is more than 1.4 logit, it gives meaning to a confusing item. On the other hand, if the MNSQ value is less than 0.6 logit, it shows that the item is too easily anticipated by the respondents (Linacre 2021). Besides that, the outfit and infit ZSTD value should also be within -2 to +2 (Bond \& Fox, 2007). But if the outfit and infit MNSQ be accepted, the ZSTD index can be ignored (Linacre 2007).

Therefore, if this condition is not met, then the item can be considered to be removed or having purified. Table 4 shows the misfit order featuring all 14 items having the range of 0.6 to 1.4 analysis statistics: misfit order. Thus from this diagnosis, there were all 14 items having purified by looking at the needs of researchers and experts. 
Table 4: Item Fit Based on MNSQ Value

|ENTRY TOTAL MODELI INFIT | OUTFIT |PT-MEASURE |EXACT MATCH | I |NUMBER SCORE COUNT MEASURE S.E. |MNSQ ZSTD|MNSQ ZSTD|CORR. EXP.| OBS\% EXP\%| Item |

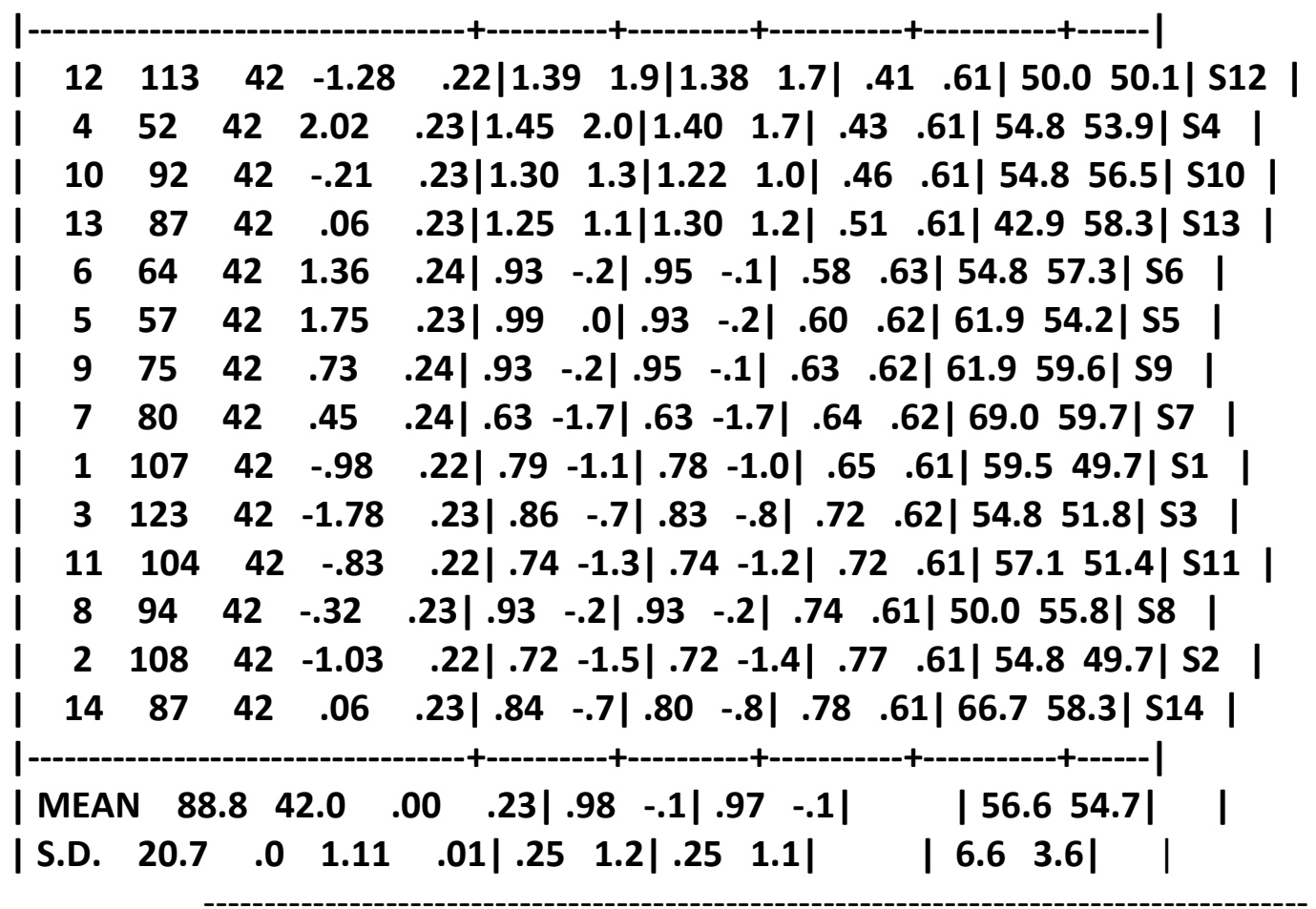

\section{Discussion and Conclusion}

All in all, the findings of this study indicated that the PSS-14 questionnaire was valid and reliable in all items. The items and respondent were shown to have high reliability and separation indices. In addition, all items appeared to fit the Rasch Measurement Model with a good five-point Likert scale. Based on the results obtained, 14 items meet the requirements analysis and should be retained.

In conclusion, the Rasch Measurement Model can be used to produce a valid and reliable instrument effectively. Thus, based on the examination of the validity and reliability of these instruments, these instruments indicate the quality of the fit to be used for the 'houseman' medical officers in Malaysia.

\section{Acknowledgement}

The authors are grateful to the Faculty of Education, Universiti Kebangsaan Malaysia for funding the publication process of this article via internal research grant (Code: GG-2019079).

\section{References}

Abdul Aziz, A., Mohamed, A., Arshad, N., Zakaria, S., \& Masodi, M. (2007). Appraisal of course learning outcomes using Rasch Measurement : A case Study in Information Technology Education. International Journal Of Systems Applications, Engineering \& Development 1(4): 164-172.

Anderson, D., \& Seib, C. (2017). The Vietnamese version of the Perceived Stress Scale (PSS- 
10): Translation equivalence and psychometric properties among older women 1-7. doi:10.1186/s12888-017-1221-6

Ariffin, S. R., Omar, B., Isa, A., \& Sharif, S. (2010). Validity and reliability multiple intelligent item using rasch measurement model. Procedia - Social and Behavioral Sciences 9: 729733. doi:10.1016/j.sbspro.2010.12.225

Askildsen, A., Dalgaard, V. L., Nielsen, K. J., Andersen, J. H., Zachariae, R., Olsen, L. R., \& Jorgensen, A. (2015). Cross-cultural adaptation and validation of the Danish consensus version of the 10-item Perceived Stress Scale. Scandinavian Journal of Work, Environment \& Health 41(5): 486-490. doi:10.5271/sjweh.3510

Bond, T. G., \& Fox, C. M. (2015). Applying the Rasch Model, $3^{\text {rd }}$ ed. New York: Routledge.

Chiu, Y. H., Lu, F. J. H., Lin, J. H., Nien, C. L., Hsu, Y. W., \& Lu, H. Y. (2016). Psychometric properties of the perceived stress scale (PSS): Measurement invariance between athletes and non-athletes. PeerJ (4:e2790): 25. doi:https://doi.org/10.7717/peerj.2790.

Cohen, S., Kamarck, T., \& Mermelstein, R. (1983). Stress a global measure of perceived. Journal of Health and Social Behavior 24(4): 385-396.

Cohen, S., \& Williamson, G. (1988). Perceived stress in a probability sample of the United States. The Social Psychology of Health 13: 31-67. Retrieved from http://doi.apa.org/psycinfo/1988-98838-002

Cooper, D. R., \& Schindler, P. S. (2012). Business Research Methods 12th Edition. Business Research Methods. New York: McGraw Hill.

Deeken, F., Häusler, A., Nordheim, J., Rapp, M., Knoll, N., \& Rieckmann, N. (2018). Psychometric properties of the Perceived Stress Scale in a sample of German dementia patients and their caregivers 39-47. doi:10.1017/S1041610217001387

Germund, M., Ørnbøl, E., Vestergaard, M., Bech, P., Breinholt, F., Lasgaard, M., \& Sparle, K. (2016). The construct validity of the Perceived Stress Scale. Journal of Psychosomatic Research 84: 22-30.

Guo, L., Jones, M. C., Liu, Y., Yv, S., Zhu, Y., \& Guo, Y. (2019). Cross-cultural validation of the student nurse Stress Index Scale : A descriptive survey targeting student nurses in China. Journal of Affective Disorders 251(September 2018): 31-38. doi:10.1016/j.jad.2019.03.017

Henrique, P., Santiago, R., Roberts, R., Smithers, L. G., \& Jamieson, L. (2019). Stress beyond coping? A Rasch analysis of the Perceived Stress Scale (PSS-14) in an aboriginal population, 1-24.

Howard, W., \& Braun, H. I. (1988). Test Validity. New York: Routledge.

Jahrami, H., Bahammam, A. S., Algahtani, H., Ebrahim, A., Faris, M., Aleid, K., \& Saif, Z. (2020). The examination of sleep quality for frontline healthcare workers during the outbreak of COVID-19. sleep and breathing 9.

Johanson, G. A., \& Brooks, G. P. (2010). Initial scale development: Sample size for pilot studies. Educational and Psychological Measurement 70(3): 1-7. doi:10.1177/0013164409355692

Kaya, C., Tansey, T. N., Melekoglu, M., Cakiroglu, O., Kaya, C., Tansey, T. N., \& Melekoglu, M. (2017). Psychometric evaluation of Turkish version of the Perceived Stress Scale with Turkish college students Psychometric evaluation of Turkish version of the Perceived Stress Scale with Turkish college students. Journal of Mental Health 0(0): 1-7. doi:10.1080/09638237.2017.1417566

Khalili, R., Masoud, S., Abbas, E., Tavallai, A., \& Habibi, M. (2018). Validity and reliability of the Cohen 10-item Perceived Stress Scale in patients with chronic headache: Persian version. 
Asian Journal of Psychiatry. doi:10.1016/j.ajp.2017.01.010

Kim, H. (2016). Reliability and Validity of the 4-Item Version of the Korean Perceived Stress Scale. Wiley Online Library 8. doi:10.1002/nur.21745

Lee, B., \& Jeong, H. I. (2019). Construct validity of the perceived stress scale (PSS-10) in a sample of early childhood teacher candidates childhood teacher candidates 0573. doi:10.1080/24750573.2019.1565693

Lee, E., Associate, R. N., Chung, B. Y., \& Suh, C. (2015). Korean versions of the Perceived Stress Scale (PSS-14, 10 and 4): Psychometric evaluation in patients with chronic disease. Scandinavian Journal of Caring Sciences (29): 183-192. doi:10.1111/scs.12131

Linacre, J. M. (2007). A User's Guide to WINSTEPS/MINISTEP Rasch-Model Computer Programs (3.91.0). Chicago. Chicago: www.winsteps.com. Retrieved from http://www.winsteps.com/a/Winsteps-ManualPDF.zip

Linacre, J. M. (2004). Test Validity and Rasch Measurement: Construct, Content, etc . Rasch Measurement Transactions. Retrieved from https://www.rasch.org/rmt/rmt181h.htm

Linacre, J. M. (2021). Winsteps Help for Rasch Analysis. New York: www.winsteps.com. Retrieved from http://homes.jcu.edu.au/ edtgb/\%5Cnpapers3://publication/uuid/D56B724A-62FF4D00-84E1-ECC888298B70

Mardare, I., \& Bratu, E. C. (2020). Measuring Stress Methods and Tools. ACTA Medica Transilvanica 25(1): 5-7. doi:10.2478/amtsb-2020-0002

Medvedev, O. N., Krägeloh, C. U., Hill, E. M., Billington, R., Siegert, R. J., Webster, C. S., \& Booth, R. J. (2017). Rasch analysis of the Perceived Stress Scale : Transformation from an ordinal to a linear measure. doi:10.1177/1359105316689603

Reis, D., Lehr, D., Heber, E., \& Ebert, D. D. (2017). The German Version of the Perceived Stress Scale (PSS-10): Evaluation of dimensionality, validity, and measurement invariance with Exploratory and Confirmatory Bifactor Modeling. Sage 1-14. doi:10.1177/1073191117715731

Ribeiro Santiago, P. H., Nielsen, T., Smithers, L. G., Roberts, R., \& Jamieson, L. (2020). Measuring stress in Australia: Validation of the perceived stress scale (PSS-14) in a national sample. Health and Quality of Life Outcomes 18(1): 1-16.

Siddiqui, F., \& Khan, R. A. (2020). Correlation between stress scores and self-regulated learning perception scores in Pakistani students. Journal of Pakistan Medicine Assosiation 70(3): 447-451.

Valéria, A., Pires, C., \& Del-ben, C. M. (2017). Perceived Stress Scale: Confirmatory factor analysis of the PSS14 and PSS10 versions in two samples of pregnant women from the BRISA cohort Escala de Estresse Percebido : análise fatorial confirmatória das versões EEP14 e EEP10 em duas amostras de gestan 33(12): 1-13. doi:10.1590/0102$311 \times 00184615$ 